\title{
Towards ecosystem based management and monitoring of the deep Mediterranean, North-East Atlantic and Beyond
}

\author{
Grehan Anthony J. 1, ${ }^{*}$, Arnaud-Haond Sophie ${ }^{2}$, D'Onghia Gianfranco ${ }^{3}$, Savini Alessandra 4, \\ Yesson Chris ${ }^{5}$
}

${ }^{1}$ Natl Univ Ireland, Sch Nat Sci, Earth \& Ocean Sci, Galway, Ireland.

2 IFREMER, UMR MARBEC Marine Biodivers Exploitat \& Conservat, Bd Jean Monnet,BP 171, F-34203 Sete, France.

3 Univ Bari Aldo Moro, LRU CoNISMa, Dept Biol, Bari, Italy.

4 Univ Milano Bicocca, LRU CoNISMa, Dept Earth \& Environm Sci, Milan, Italy.

${ }^{5}$ Zool Soc London, Inst Zool, Regents Pk, London NW1 4RY, England.

* Corresponding author : Anthony J. Grehan, email address : Anthony.Grehan@nuigalway.ie

Keywords : deep-water corals, fish, fisheries, ecosystem based management, habitat suitability modelling, monitoring, conservation, litter, climate change 


\section{Introduction}

The deep sea covers $65 \%$ of the earth's surface and $95 \%$ of the biosphere but only a very small fraction (less than $0.0001 \%$ ) of this has been explored (Rogers et al., 2015; Taylor and Roterman, 2017). However, current knowledge indicates that the deep ocean is characterized by a high level of biodiversity and by the presence of important biological and non-renewable resources. As well as vast flat and muddy plains, the topography of the deep ocean contains a variety of complex and heterogeneous seafloor features, such as canyons, seamounts, cold seeps, hydrothermal vents and biogenic (deep-water coral) reefs and sponge bioherms that harbour an unquantified and diverse array of organisms. The deep sea, despite its remoteness, provides a variety of supporting, provisioning, regulating and cultural, ecosystem goods and services (Thurber et al., 2014). The recent push for 'Blue Growth', to unlock the potential of seas and oceans (European Commission, 2017) has increased the focus on the potential to exploit resources in the deep-sea and consequently the need for improved management (Thurber et al., 2014).

Ecosystem-based management (EBM) can be defined as an integrated approach to management that aims to maintain an ecosystem in a healthy, productive and resilient condition while providing the services that humans want and need (McLeod et al., 2005). While Cormier et al. (2016) argue that scientific impediments to EBM are no longer significant to prevent operational implementation, a lack of basic scientific knowledge still hinders its full realisation in the deep sea. Area-based management, particularly within a formal marine spatial planning framework, is now regarded as an essential component of EBM. In the European Union, the Maritime Spatial Planning Directive (MSP Directive 2014/89/EU) provides a means to integrate area-based management measures 
required under sectoral policy, such as the EU Habitats Directive, Marine Strategy Framework Directive and the Common Fisheries Policy. In international waters, the United Nations General Assembly adopted Resolution 69/292 to develop an international legally binding instrument under the United Nations Convention on the Law of the Sea (UNCLOS) on the conservation and sustainable use of marine biological diversity in areas beyond national jurisdiction, also known as the UN BBNJ process. The preparatory phase concluded with a fourth and final meeting of the UN BBNJ Preparatory Committee in June 2017. They recommended that the negotiation of the new BBNJ regulation include area-based management as one of the priority strands (Earth Negotiations Bulletin 2017). This builds on previous UN resolutions such as the UNGA Resolution 61/105, agreed to in 2006, that calls upon fisheries management organisations worldwide to: i) assess the impact of bottom fishing on vulnerable marine ecosystems (sensu FAO 2009); ii) identify/map vulnerable ecosystems through improved scientific research/data collection; iii) close such areas to bottom fishing unless conservation and management measures are established to prevent their degradation.

This special issue reports on research undertaken in Europe as part of the European Union Framework Project 'CoralFISH' (2008-2013; www.eu-fp7-coralfish.net) to improve the scientific basis for ecosystem-based resource management and monitoring in the deep waters of the Mediterranean and the North Atlantic in addition to addressing the need for tools and data to support implementation of UNGA 61/105. By focusing on the interactions between coral, fish and fisheries, the outputs from the CoralFISH project, equally address current issues relating to implementation of area based management particularly the adequacy of conservation measures in the deep sea. CoralFISH brought together a unique consortium of deep-sea fisheries biologists, ecosystem researchers/modellers, marine geologists, oceanographers, economists and a fishing industry partner, from 11 countries, who collaborated to collect data from all of the key European marine eco-regions (ICES, 2004) where cold-water corals are found (Fig. 1).

The main objectives of the CoralFISH project were:

- Development of essential methodologies and indicators for baseline and subsequent monitoring of closed areas,

- Better understanding of coral habitat fish-carrying capacity through the integration of fish data into coral ecosystem models,

- The evaluation of the distribution of deep-water bottom fishing effort to identify areas of potential interaction and impact upon coral habitat,

- The use of genetic fingerprinting to assess the potential erosion of genetic fitness of corals due to long-term exposure to fishing impacts,

- The construction of bio-economic models to assess the impact on fisheries of various management measures adopted to protect coral habitat,

- The production of habitat suitability maps to identify areas likely to contain vulnerable marine habitat.

\section{Key outputs from the CoralFISH project}

\subsection{Determining the importance of cold-water corals as fish habitat}

\subsubsection{Cold-water coral reefs and fish}

One of the key objectives of the CoralFISH project was to determine the importance of coral habitat for fish. The project employed a variety of standardised methodologies involving on reef/off reef comparisons using fisheries acoustics, longlining and video transects. In Norway, Kutti et al. 
(2014, 2015) examined the relationship between demersal fish distributions and benthic habitats in: i) the Træna Deep marine protected area and adjacent areas of the Norwegian continental shelf using standardised longlining surveys, and in ii) the Trænadjupet marine protected area using a towed video system. Results from the longline surveys showed positive correlations between catch rates of tusk, Brosme brosme, the blackmouth catshark, Galeus melastomus and the rabbit fish, Chimaera monstrosa and density of small cold-water coral (CWC) mounds (Kutti et al., 2014). The authors noted, however, that differences in catch rates between coral and non-coral areas were quite low and that for most species the fish-habitat relationships varied temporarily and with the spatial scale used to delineate the habitat. Results from the towed video surveys indicate that the redfish, Sebastes viviparus and B. brosme, were twice as abundant in areas with coral habitats than in unstructured flat seabed at spatial scales from $<3 \mathrm{~m}$ to $2 \mathrm{~km}$ (Kutti et al., 2015). None of the fish species examined in Trænadjupet were confined exclusively to a single habitat; the authors thus concluded that fish are facultative users of coral habitat.

In the Santa Maria di Leuca (SML) CWC province (Mediterranean Sea), D'Onghia et al. (2012) compared deep-sea fish fauna in coral and noncoral mega-habitats using experimental longline surveys. They found some species specific differences in density and biomass between coral and non-coral mega-habitats. The blackspot seabream, Pagellus bogaraveo was exclusively collected in the coral mega-habitat, whereas the European conger, Conger conger, the blackbelly rosefish, Helicolenus dactylopterus and the wreckfish, Polyprion americanus were found with greater abundance in coral than in non-coral mega-habitat. The benthopelagic fauna of this Mediterranean cold-water coral province was further investigated using a baited lander in 2010 and 2011. The occurrence of P. bogaraveo exclusively in coral habitat was confirmed. The crustacean Paromola cuvieri and C. conger and $\mathrm{H}$. dactylopterus were the most abundant species in coral habitat (Maiorano et al., 2013). The occurrence and behaviour of P. cuvieri and sharks: gulper (Centrophorus granulosus), kitefin (Dalatias licha), velvet belly lantern (Etmopterus spinax) and bluntnose sixgill (Hexanchus griseus), in coral areas of the SML CWC province were also recorded (Capezzuto et al., 2012; Sion et al., 2013).

Understanding the temporal interaction of fish with coral reefs requires novel technological solutions. Autonomous photographic landers provide a low-impact survey method that can be used in and around reefs (Linley et al., 2017). Lavaleye et al. (2017) describe testing of a new baited camera system deployed on a carbonate mound, off the west coast of Ireland. They provide a detailed description of their system and describe some of the technical challenges they faced in the field. A variety of fish and scavenging invertebrates were observed with varied frequency although no seasonal patterns were detected. Linley et al. (2017) describe the deployment of autonomous landers in the Arctic (Northern Norway), NE Atlantic (Belgica Mound Province and Bay of Biscay) and the Mediterranean (Santa Maria di Leuca CWC province). Observations were standardised between the different lander systems and comparisons made between coral and reference stations in each location. Fish abundance was shown to be higher within coral areas in all cases. Species diversity was higher within Atlantic coral areas compared to Arctic and Mediterranean sites. In the Arctic and Mediterranean sites, although diversity levels were similar at both coral and reference stations, coral areas were characterised by dominance by a single species (Brosme brosme in the Arctic and Conger conger in the Mediterranean). The authors contend that the results indicate that coral areas have a positive effect on fish diversity and/or abundance but the effect is more or less pronounced across Europe's reefs.

\subsubsection{Coral gardens and fish}

Several studies describe the interaction of fish with soft corals (Brodeur, 2001; Mortensen et al., 2005; Busby et al., 2006; Etnoyer and Warrenchuk, 2007; Baillon et al., 2012; Miller et al., 2015; Ross et al., 2015; Brooke et al., 2017). In the Azores, (Pham et al., 2015) investigated the 
importance of vulnerable marine ecosystems (VMEs) (CWC and sponges) in influencing the distribution of demersal fish using data collected during experimental longline surveys. They found that while total fish catch was higher inside VMEs, the relationship between fish and VMEs varied among fish species, and only two rockfish species; juvenile and adult Pontinus kuhlii and juvenile Helicolenus dactylopterus showed a strong association with VMEs. Also in the Azores, GomesPereira et al. (2017) address the association between two deep-sea fish species with low mobility, the Iris wrasse, Lappanella fasciata and the Robust Cusk-eel, Benthocometes robustus, with a range of soft corals based on the analysis of twenty years of in situ image survey data of continental slope and seamounts from the Azores to the Canary Islands. The authors found that L. fasciata tended to swim within or close to, large and tall corals or hydroids, while B. robustus was always found between coral branches exhibiting a type of coral-cryptic behavior.

These authors contend that these observations indicate that cold-water corals and hydroid gardens act as essential fish habitat for both species. Parra et al. (2017) adopted a different approach to assess links between corals and fish. They looked for overlap between the modeled distribution of eight commercially important fish species and known coral areas. Despite some caveats, validation of the models provided reasonable confidence in the fish species predicted distributions. Primarily controlled by depth, fish occurrence appears to be patchy and tends to be confined to seamount slopes and summits, offshore banks and island slopes; areas also favoured by cold-water corals.

\subsubsection{Cold-water coral reefs and fisheries}

While bioeconomic analyses show that cold-water corals may provide direct provisioning, regulating and cultural services, their main ecosystem service is to provide habitat and support enhanced species biodiversity (Armstrong et al., 2014). Applying an economic production function approach to estimate the link between Norway redfish (Sebastes viviparus) and cold-water corals off the Norwegian coast, Foley et al. (2010) found both the carrying capacity and growth rate of redfish were functions of the extent of cold-water coral habitat and thus cold-water corals could be considered an essential fish habitat. This suggests that loss of coral habitat (and thus carrying capacity) due to trawling would impact the profitability of the fishery due to reductions in fish available for harvest. The authors recommended that protection of essential fish habitat be considered when managing commercially important fish species.

\subsection{Mapping the distribution of cold-water corals/VMEs and fish in the deep sea}

Only a small percentage of the deep-sea floor has been mapped with the detail required to identify the extent of vulnerable marine ecosystems in any given area (Ragnarsson et al., 2016). The CoralFISH project undertook to map CWC habitat across a variety of scales from meso to microscale through the compilation of existing data and the generation of new seafloor maps where gaps existed using standardised approaches to data collection and visualisation. Extensive new coral habitat maps were produced for canyons in the Bay of Biscay (Bourillet et al., 2012; van den Beld et al., 2017) and the Santa Maria di Leuca CWC province, Italy (Savini et al., 2014). Taviani et al. (2017) describe a new cold-water coral (CWC) province in the Capo Spartivento canyon system off the southern coast of Sardinia. The dominant coral is Madrepora oculata found between depths of 380 to $460 \mathrm{~m}$. Intermediate between known CWC provinces in the east and west of the basin, this find confirms the influence of Levantine Intermediate Water on CWC distribution in the Mediterranean and plugs a major gap connecting coral populations across the basin.

Despite efforts to map CWC habitat, large areas of the ocean floor harboring vulnerable marine ecosystems remain unexplored. To respond to the UNGA 61/105 requirement to map VMEs in ABNJ, the CoralFISH project focused on the development and application of habitat suitability 
modelling (Rengstorf et al., 2012; Rengstorf et al., 2013; Mohn et al., 2014; Rengstorf et al., 2014) and the identification of key geomorphology features (Yesson et al., 2011; Savini et al., 2014) that could help predict where VMEs were likely to be found in areas where data are lacking. Initial global models of CWC distribution focused on reef building corals, especially Lophelia pertusa (Davies and Guinotte, 2011) and only more recently on soft corals, such as the octocorals (Yesson et al., 2011) and Antipatharia (Yesson et al., 2017). The Antipatharia are a diverse group of long-lived but fragile corals that can form a major component of 'coral gardens' and are thus considered as VMEs. A global map of predicted habitat distribution (Yesson et al., 2017) showed that Antipatharia have a strong habitat preference for continental shelves, shelf edges and ridges. Distribution is strongly influenced by temperature but also topographic features particularly those likely to contain areas of exposed rock.

\subsection{Assessing the impact of bottom fishing on vulnerable marine ecosystems}

A variety of human activities can impact cold-water corals and evaluating the magnitude of their spatial interactions requires data with the highest possible spatial resolution (Ragnarsson et al., 2016). Benn et al. (2010) estimated the spatial footprint of all human activities occurring in the North-East Atlantic in 2005. They identified trawling as the major impact and since then a number of papers have developed methodologies to quantify the footprint of bottom trawling in European waters (Gerritsen et al., 2013; Eigaard et al., 2016). Pham et al. (2014a) in comparing the impacts from trawling and deep-sea bottom longline fishing, demonstrated that longline fishing has a greatly reduced impact on vulnerable marine ecosystems. D’Onghia et al. (2017) present data on the overlap between fishing activity and CWC in the Santa Maria di Leuca CWC province, south of the heel of Italy. They collated data on longlining and trawling activities from an observer program as well as through analysis of Vessel Monitoring System records, proving that trawlers still often fish inside the Fisheries Restricted Area (FRA) within the SML CWC province. Moreover, the authors used a camera system to find evidence of fishing impacts in CWC related to fishing activity. Impacts of longline fishing were evident through observations of lost gear while otter board scars resulting from trawling impacts were also discernable.

\subsection{Classifying cold-water coral biotopes}

The development of a comprehensive European cold-water coral habitat inventory (catalogue) based largely on newly obtained in situ video and photographs provides for the first time, a detailed description of the variation in coral habitats encountered in European oceans and seas (Davies et al., 2017). A total of 81 coral biotopes are identified dominated by reef-building scleractinians (living and dead reefs, dense framework, loosely packed framework, rubble, isolated colonies and solitary scleractinians, antipatharians, Alcyoniina, gorgonians, pennatulids or stylasterids), and two non-stylasterid hydrarians. The CWC habitats were classified where possible by making reference to existing categories described in: (i) the Habitats Directive, (ii) the OSPAR list of threatened and/or in decline habitats and (iii) the European Environment Agency - European Union Nature Information Scheme (EUNIS) classification. The great variety of coral biotopes identified by Davies et al. (2017) don't currently feature in these classification schemes, however the CWC biotope classification scheme proposed by Davies et al. (2017) could be easily incorporated by these existing schemes so that they better represent VMEs. CWC habitats have been identified on sand and mud (soft bottoms) traditionally considered to be non-coral areas and exploitable by fishing. The potential impact on these corals should be factored into the future management of offshore activities. 


\subsection{Current conservation concerns}

\subsubsection{Reproduction and Connectivity}

Understanding the potential of reefs and coral gardens to recover from impacts is vital to inform species conservation and management (Roberts et al., 2006). The delivery of a large-scale picture of the distribution of intra-specific (genomic) diversity as well as connectivity patterns among European reefs can help optimize the representativeness and connectivity of Marine Protected Areas networks aimed at protecting cold-water coral reefs or other VME species (Arnaud-Haond et al., 2017). Reefs form through the intermingling of individual colonies initiated by successful settlement of coral larva. Over time, colonies fragment primarily due to weakening of branches by bio-erosion. Some of these broken branches remain viable and reform colonies asexually via monostomaeous budding (Henry and Roberts, 2014) while unburied non-viable branches provide sites for fresh larval settlement (Wilson, 1979). Reefs are maintained or expand by the addition of new colonies initiated by fresh larval recruitment or asexual propagation via fragmentation. The contribution of each method to reef maintenance/expansion and thus the degree of genetic differentiation in a given area has been little studied in the deep sea.

Measures of clonality are used in shallow waters to assess the dynamics of clonal and genetic diversity in sea-grass populations (Becheler et al., 2014). Replicating similarly robust statistical sampling methodologies in the deep sea to determine clonality in corals is technically demanding. Becheler et al. (2017) present a novel methodology describing a standardised, random and georeferenced sampling protocol using the advanced capabilities of the IFREMER Remotely Operated Vehicle 'Victor' to assess the spatial pattern and extent of clonality in Lophelia pertusa and Madrepora oculata reefs in the Bay of Biscay. They demonstrate that such a methodology can be applied in the deep sea leading to improved estimates of fine grained patterns of clonality and dispersal that are comparable across sites and among species. Using this sampling approach, they found low levels of clonality in both L. pertusa and M. oculata indicating that sexual reproduction is dominant. When clonality was recorded, cloned colonies were generally found close to the parent colony indicating that the occurrence of clonal extension (reefs formed by a succession of cloned colonies) is rare in the Bay of Biscay. Interestingly, at one site, cloned colonies were found at some distance from the parent colony and the authors contend that this was most likely due to mechanical dispersion of coral fragments during demersal fishing that may lead to an increase in the prevalence of clonal reproduction.

Even less is known about the ecology and reproductive biology of non-reef forming corals, i.e. the majority of deep-sea soft coral species. Rakka et al. (2017) studied the black coral Antipathella wollastoni, an antipatharian common to Macaronesia in depths between 20 and $1425 \mathrm{~m}$. They found that A. wollastoni is a gonochoric broadcast spawner with an annual cycle. Polyp fecundity ranged from 1 to 309 oocytes/polyp and is positively correlated with colony height indicating that reproductive output increases with colony size (with implications for conservation). The importance of asexual reproduction in the species remains to be determined but the authors note that in a related species, asexual reproduction, possibly through polyp bail-out and recruitment of asexual larvae does occur.

\subsubsection{Marine protected areas}

In the NE Atlantic, the two principal reef-constructing corals, Madrepora oculata and Lophelia pertusa co-occur almost systematically, however, the relative importance of each in reef construction has never been subject to rigorous assessment. Arnaud-Haond et al. (2017) carried out detailed qualitative and quantitative Remotely Operated Vehicle (ROV) surveys at sites from the Bay of Biscay to Iceland and found that abundances of both species were similar in all reefs studied. The term "Lophelia reef" may therefore be an oversimplification with ramifications for 
conservation management as the ecology and populations dynamics of M. oculata should be addressed when protected area networks are established.

The degree of representiveness of current arrangements to protect CWC in Irish waters, under the EU Habitats Directive, was assessed using high resolution habitat suitability model derived predicted coral reef distributions (Rengstorf et al., 2013). Habitat suitability model outputs were converted into predictions of presence and absence by applying a threshold value. While selection of an appropriate threshold can be somewhat arbitrary and results must be treated with caution (Yesson et al., 2017) useful information in the absence of detailed surveys can be produced. Rengstorf et al. (2013) demonstrated from model outputs, that further conservation of reefs is needed to ensure a more complete representation of the variety of reef assemblages found in Irish waters. Using a similar approach, Yesson et al. (2017), assessed the degree of protection afforded to Antipatharia by overlaying the outputs from their model with the known extent of global marine protected areas. The authors demonstrated that although 25\% of Antipatharia observations are located in MPAs, only 7-8\% of predicted suitable Antipatharian habitat is protected globally, which is well short of the Convention on Biological Diversity target to protect $10 \%$ of ocean habitats by 2020.

In the Mediterranean, D’Onghia et al. (2017) describe anthropogenic impacts in the Santa Maria di Leuca CWC province and review the effectiveness of the current conservation and management regime. They demonstrate that fishing is taking place within a Fisheries Restricted Area (FRA) that bans dredges and bottom trawling. They consider that a lack of monitoring, control and surveillance has rendered the FRA ineffective and that strengthening of conservation and management initiatives is urgently required to prevent further overexploitation and habitat loss. Taviani et al. (2017) call for the development of a new high-sea Marine Protected Area to conserve the newly discovered VMEs in the Capo Sparivento canyons. The need to protect VMEs in canyons is echoed by D'Onghia et al. (2015) and van den Beld et al. (2017) who call for protection measures to be put in place in the Bari Canyon (Mediterranean) and the Bay of Biscay (France), respectively. Such initiatives would contribute to a global effort to better protect canyon habitats (Harris and Whiteway, 2011; Fernandez-Arcaya et al., 2017).

In Areas Beyond National Jurisdiction, (Auster et al., 2010) identified problems with the implementation of the FAO guidelines for the management of deep-sea fisheries (FAO, 2009) particularly with regards uncertainties about the location of VMEs and their resilience. They recommended that large-scale permanent closed areas with prohibition of bottom-contact fishing should be part of a suite of measures needed to adopt a precautionary approach to management of fisheries in areas likely to contain VMEs.

\subsubsection{Marine Litter}

Marine litter is a current hot topic and sadly there is ample evidence of litter deposited on the deepsea floor in CWC habitats (e.g. Grehan et al., 2005; Pham et al., 2013; Pham et al., 2014b; Lastras et al., 2016; Rodríguez and Pham 2017). Ensuring that marine litter does not harm the marine environment is the focus of Descriptor 10, one of 11 Good Environmental Status (GES) descriptors under the European Union Marine Strategy Framework Directive (MSFD Directive 2008/56/EC). European Member States are required to achieve GES by 2020 considering all 11 descriptors. D’Onghia et al. (2017) enumerated litter encounters during their camera surveys in the SML CWC province and noted that plastics were the most abundant litter in CWC habitats. This confirmed the observations of Savini et al. (2014) that plastic bags entangled in live and dead coral branches were only found in CWC. The high abundance of plastic bags in coral-dominated habitats seems to be related to the 'trapping effect' of branching colonial corals located on geomorphological highs exposed to the strong currents that tend to gather plastic material (Savini et al., 2014). 
An extensive survey of litter in CWC habitats canyons of the Bay of Biscay, France, is reported in van den Beld et al. (2017). The authors also enumerated all litter encounters visible in video taken during habitat mapping surveys. Litter was shown to be widely distributed in the submarine canyons of the Bay of Biscay and again, plastic items were seen to be most abundant followed by fishing-related items. Some litter items were colonised by scleractinian corals and hydroids. Rodríguez and Pham (2017) noted that over 50\% of litter items recorded during surveys of the seafloor of the Azorian Faial-Pico Passage were colonised by sessile invertebrates and algal species. This prevalence of plastic items in CWC lends credence to the assertion by Woodall et al. (2014) that the deep sea is a major repository for micro-plastics and plastics are being ingested by deepsea fish (Anastasopoulou et al., 2013) and invertebrates (Taylor et al., 2016).

\subsubsection{Climate change}

Cold-water coral reefs are hotspots of carbon processing in the food-limited deep ocean (Van Oevelen et al., 2009) and may play a more prominent role in marine biogeochemical cycles than previously recognized (Cathalot et al., 2015). In the Træna Coral Field, Norway, in situ community respiration oxygen uptake rates over coral reefs were 9-20 times higher than those of the surrounding soft sediments. Cathalot et al. (2015) contend that such high respiration rates indicate strong organic matter consumption, and hence suggest a local focusing of the downward flux of organic matter exported from the surface ocean onto the reefs. Soetaert et al. (2016) inferred the mechanism by which such benthic-pelagic coupling is possible using model simulations. They describe the presence of a 'topographically-enhanced carbon pump' that transports surface organic matter to 600-m deep CWCs mounds off the west coast of Ireland and suggest that corals act as ecosystem engineers, in that the presence of coral reefs reinforces the local topographic interaction with tidal currents thus ensuring increased food supply. Climate change that leads to an expected increase in stratification and lower surface productivity, may disrupt this focused flow of energy from surface to deep (Soetaert et al., 2016).

\section{Concluding Remarks}

Implementing marine spatial planning in the deep sea in support of ecosystem-based management presents challenges due to patchy data availability. The output of the CoralFISH project and the papers presented in this issue have added to our knowledge of the distribution and types of cold-water coral/VMEs present in European waters and beyond, their importance as habitat for fish and the need to continue with and indeed extend conservation efforts to protect them. Large integrated collaborative projects such as CoralFISH have an important role in improving the scientific knowledge base to support and ensure exploitation of deep-sea resources is environmentally sustainable with an emphasis on the conservation of vulnerable marine ecosystems and biodiversity. CoralFISH, via a well-developed science-policy interface, contributed to important policy developments:

i) the revised EU Deep-Sea Access Regime that bans trawling below $800 \mathrm{~m}$ and requires special measures to protect VMEs below 400m;

ii) the implementation of the FAO International Guidelines for the Management of Deep-Sea Fisheries (Auster et al., 2010), iii) the identification of Ecological or Biological Significant Marine Areas in the NE Atlantic (Yesson et al., 2012; Yesson et al., 2017); and, iv) the application of the EU Marine Strategy Framework Directive in the deep sea.

It's of interest to note that the CoralFISH is one in a long line of large European integrated projects dedicated to improving the science basis for sustainable management of deep-sea resources funded since the turn of the century beginning with the EU FP5 ACES - Atlantic Coral Ecosystem Study from 2001-2004 (Freiwald, 2002) and followed by EU FP6 HERMES - Hotspot Ecosystem Research on the Margin of European Seas from 2004-2009 (Grehan et al., 2009), EU FP7 HERMIONE - Hotspot Ecosystem Research and Man's Impact On European Seas from 2009-2013 
(Weaver et al., 2009) and EU FP7 Midas - Managing Impacts of Deep-sea resource exploitation from 2013-2016 (www.eu-midas.net). The baton has now been taken up by the EU H2020 projects: Atlas - A Trans-Atlantic assessment and deep-water ecosystem-based spatial management plan for Europe (http://www.eu-atlas.org) and Sponges - Deep-sea Sponge Grounds Ecosystems of the North Atlantic (www.deepseasponges.org) that are well placed to inform discussions at the proposed Intergovernmental Conference tasked with drafting the future UN BBNJ Regulation.

\section{Acknowledgements}

This Special Issue presents some of the findings from the EU-FP7 CoralFISH project (grant no. 213144). The guest editors would like to thank the anonymous referees who give of their time and advice during the review process. We would also like to thank the CoralFISH EC project officer Ana-Teresa Caetano for her wisdom and support during the lifetime of the project. One of us, AJG, is partially supported by the EU H2020 ATLAS project (Grant Agreement: 678760). The opinions reflect only the author's view and the European Union cannot be held responsible for any use that may be made of the information contained therein. 


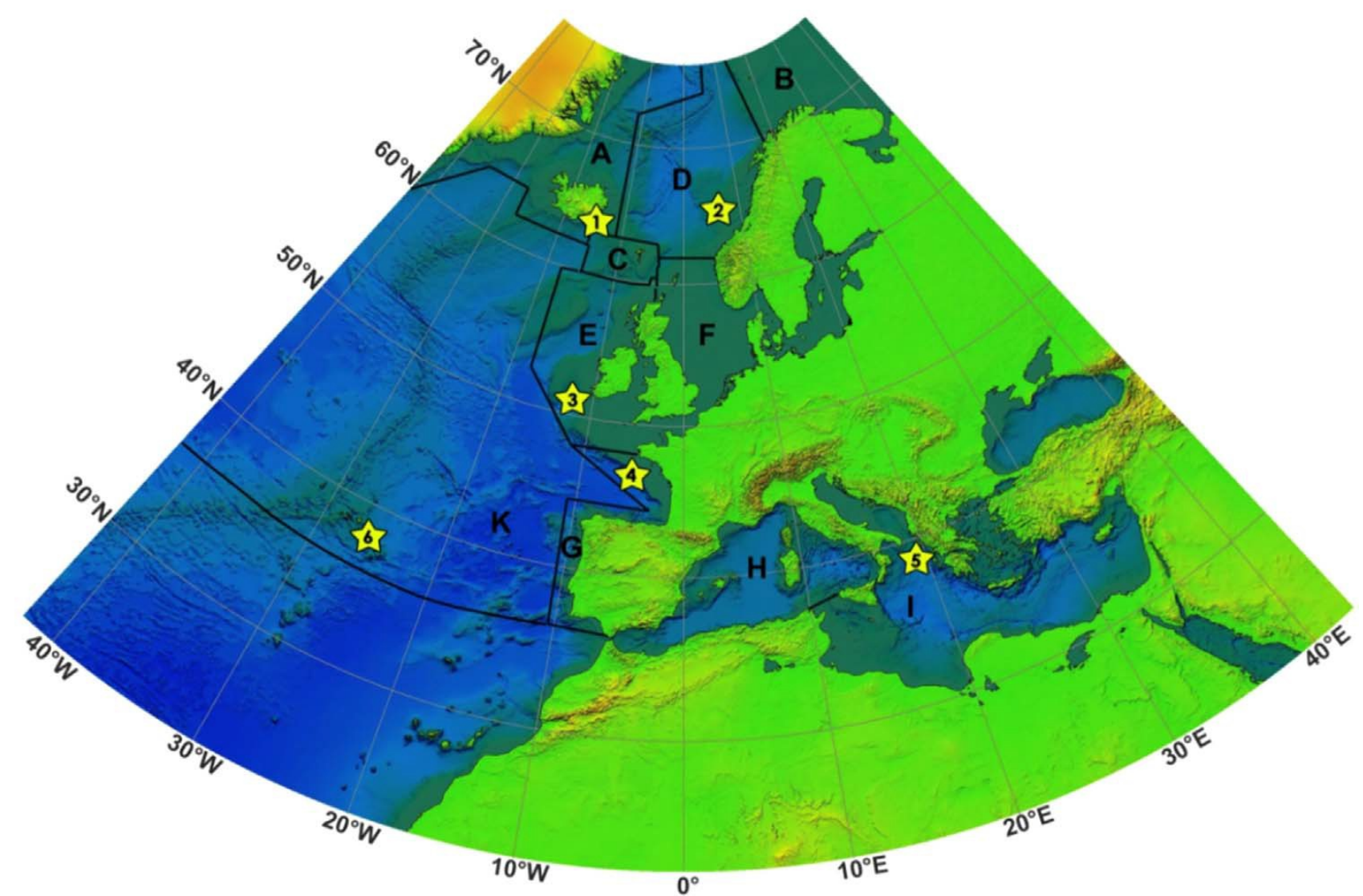

Fig. 1. Schematic representation of the 6 regional study areas of the CoralFISH project (cf. Davies et al., 2017). The 6 study areas are located; (1) offshore south Iceland (biogeographic region A); (2) offshore Norway (biogeographic region D); (3) offshore western Ireland (Porcupine Bank and Seabight, and Rockall Trough, within biogeographic region E); (4) offshore western France (Bay of Biscay, biogeographic region G); (5) offshore Italy and Greece in the Eastern Mediterranean sea (Northern Ionian sea, biogeographic region I) and (6) in the Azores archipelago (biogeographic region $K)$.

\section{References}

Anastasopoulou, A., Mytilineou, C., Smith, C.J., Papadopoulou, K.N., 2013. Plastic debris ingested by deep-water fish of the Ionian Sea (Eastern Mediterranean). Deep Sea Research Part I: Oceanographic Research Papers 74, 11-13. http://dx.doi.org/10.1016/j.dsr.2012.12.008. Armstrong, C.W., Foley, N.S., Kahui, V., Grehan, A., 2014. Cold water coral reef management from an ecosystem service perspective. Marine Policy 50, 126-134. http://dx.doi.org/10.

1016/j.marpol.2014.05.016.

Arnaud-Haond, S., Van den Beld, I.M.J., Becheler, R., Orejas, C., Menot, L., Frank, N., Grehan, A. \& Bourillet, J.F., 2017. Two "pillars" of cold-water coral reefs along Atlantic European margins: Prevalent association of Madrepora oculata with Lophelia pertusa, from reef to colony scale. Deep Sea Research Part II: Topical Studies in Oceanography, 145, 110-119.http:// dx.doi.org/10.1016/j.dsr2.2015.07.013.

Auster, P.J., Gjerde, K., Heupel, E., Watling, L., Grehan, A., Rogers, A.D., 2010. Definition and detection of vulnerable marine ecosystems on the high seas: problems with the "move-on" rule. ICES Journal of Marine Science 68, 254-264. http://dx.doi.org/10.1093/icesjms/fsq074. Baillon, S., Hamel, J.F., Wareham, V.E., Mercier, A., 2012. Deep cold-water corals as nurseries for fish larvae. Frontiers in Ecology and the Environment 10, 351-356. http://dx.doi.org/ 10.1890/120022. 
Becheler, R., Benkara, E., Moalic, Y., Hily, C., Arnaud-Haond, S., 2014. Scaling of processes shaping the clonal dynamics and genetic mosaic of seagrasses through temporal genetic monitoring. Heredity (Edinb) 112, 114-121. http://dx.doi.org/10.1038/hdy.2013.82.

Becheler, R., Cassone, A.-L., Noël, P., Mouchel, O., Morrison, C.L. \& Arnaud-Haond, S., 2017. Low incidence of clonality in cold water corals revealed through the novel use of a standardized protocol adapted to deep sea sampling. Deep Sea Research Part II: Topical Studies in Oceanography, 145,120-130. http://dx.doi.org/10.1016/j.dsr2.2015.11.013.

Benn, A.R., Weaver, P.P., Billet, D.S., van den Hove, S., Murdock, A.P., Doneghan, G.B., Le Bas, T., 2010. Human activities on the deep seafloor in the North East Atlantic: an assessment of spatial extent. PLoS ONE 5, e12730. http://dx.doi.org/10.1371/journal.pone.0012730.

Bourillet, J.-F., de Chambure, L. \& Loubrieu, B. 2012. Cold water corals of the Bay of Biscay: 8 bathymorphological and geomorphological maps at 1:100,000. Editions Quae.

Brodeur, R.D., 2001. Habitat-specific distribution of Pacific ocean perch (Sebastes alutus) in Pribilof Canyon, Bering Sea. Continental Shelf Research 21, 207-224.

Brooke, S.D., Watts, M.W., Heil, A.D., Rhode, M., Mienis, F., Duineveld, G.C.A., Davies, A.J., Ross, S.W., 2017. Distributions and habitat associations of deep-water corals in Norfolk and Baltimore Canyons, Mid-Atlantic Bight, USA. Deep Sea Research Part II: Topical Studies in Oceanography 137, 131-147. http://dx.doi.org/10.1016/j.dsr2.2016.05.008.

Busby, M.S., Orr, J.W., Blood, D.M., 2006. Eggs and late-stage embryos of Allocareproctus unangas (family Liparidae) from the Aleutian Islands. Ichthyological Research 53, 423-426. http://dx.doi.org/10.1007/s10228-006-0361-3.

Capezzuto, F., Maiorano, P., Panza, M., Indennidate, A., Sion, L., D'Onghia, G., 2012. Occurrence and behaviour of Paromola cuvieri (Crustacea, Decapoda) in the Santa Maria di Leuca cold-water coral community (Mediterranean Sea). Deep-Sea Research Part I: Oceanographic Research Papers 59, 1-7. http://dx.doi.org/10.1016/j.dsr.2011.10.006.

Cathalot, C., Van Oevelen, D., Cox, T.J.S., Kutti, T., Lavaleye, M., Duineveld, G., Meysman, F.J.R., 2015. Cold-water coral reefs and adjacent sponge grounds: Hotspots of benthic respiration and organic carbon cycling in the deep sea. Frontiers in Marine Science 2. http://dx.doi.org/10.3389/fmars.2015.00037.

Cormier, R., Kelble, C.R., Anderson, M.R., Allen, J.I., Grehan, A., Gregersen, Ó., 2016. Moving from ecosystem-based policy objectives to operational implementation of ecosystem-based management measures. fsw. ICES Journal of Marine Science: Journal du Conseil 181. http://dx.doi.org/10.1093/icesjms/fsw181.

D'Onghia, G., Maiorano, P., Carlucci, R., Capezzuto, F., Carluccio, A., Tursi, A., Sion, L., 2012. Comparing Deep-Sea Fish Fauna between Coral and Non-Coral "Megahabitats" in the Santa Maria di Leuca Cold-Water Coral Province (Mediterranean Sea). PLoS ONE 7. http://dx.doi.org/10.1371/journal.pone.0044509.

D'Onghia, G., Capezzuto, F., Cardone, F., Carlucci, R., Carluccio, A., Chimienti, G., Corriero, G., Longo, C., et al., 2015. Macro- and megafauna recorded in the submarine Bari Canyon (southern Adriatic, Mediterranean Sea) using different tools. Mediterranean Marine Science 16, 180-196. http://dx.doi.org/10.12681/mms.1082.

D’Onghia, G., Calculli, C., Capezzuto, F., Carlucci, R., Carluccio, A., Grehan, A., Indennidate, A., Maiorano, P., et al., 2017. Anthropogenic impact in the Santa Maria di Leuca cold-water coral province (Mediterranean Sea): Observations and conservation straits. Deep Sea Research Part II: Topical Studies in Oceanography, 145,87-101. http://dx.doi.org/10.1016/j.dsr2.

2016.02.012.

Davies, A.J., Guinotte, J.M., 2011. Global habitat suitability for framework-forming cold-water corals. PLoS ONE 6. http://dx.doi.org/10.1371/journal.pone.0018483.

Davies, J.S., Guillaumont, B., Tempera, F., Vertino, A., Beuck, L., Ólafsdóttir, S.H., Smith, C.J., Fosså, J.H., et al., 2017. A new classification scheme of European cold-water coral habitats: 
Implications for ecosystem-based management of the deep sea. Deep Sea Research Part II: Topical Studies in Oceanography, 145,102-109. http://dx.doi.org/10.1016/j.dsr2.2017.04.

014.

Earth Negotiations Bulletin, 2017. Summary of the Fourth Session of the Preparatory Committee on Marine Biodiversity Beyond Areas of National Jurisdiction. 10-21 July 2017. IISD

Reporting Services 25.

Eigaard, O.R., Bastardie, F., Hintzen, N.T., Buhl-Mortensen, L., Buhl-Mortensen, P., Catarino, R., Dinesen, G.E., Egekvist, J., et al., 2016. The footprint of bottom trawling in European waters: distribution, intensity, and seabed integrity. fsw. ICES Journal of Marine Science: Journal du Conseil 194. http://dx.doi.org/10.1093/icesjms/fsw194.

Etnoyer, P., Warrenchuk, J., 2007. A catshark nursery in a deep Gorgonian field in the Mississippi

Canyon, Gulf of Mexico. Bull. Mar. Sci. 8, 553-559.

European Commission, 2017. Report on the Blue Growth Strategy: Towards more sustainable growth and jobs in the blue economy. Commission Staff Working Document SWD(2017) 128 final.

FAO, 2009. Report of the Technical Consultation on International Guidelines for the Management of Deep-sea Fisheries in the High Seas. FAO Fisheries and Aquaculture Report 881, 1-86.

Fernandez-Arcaya, U., Ramirez-Llodra, E., Aguzzi, J., Allcock, A.L., Davies, J.S., Dissanayake, A., Harris, P., Howell, K., et al., 2017. Ecological Role of Submarine Canyons and Need for Canyon Conservation: A Review. Frontiers in Marine Science 4.

http://dx.doi.org/10.3389/fmars.2017.00005.

Foley, N.S., Kahui, V., Armstrong, C.W., van Rensburg, T.M., 2010. Estimating Linkages between Redfish and Cold Water Coral on the Norwegian Coast. Marine Resource Economics 25, 105-120.

Freiwald, A., 2002. Reef-Forming Cold-Water Corals. In: Wefer, G., Billet, D.S., Hebbeln, D., Jorgensen, B.B., Schlüter, M., Van Weering, T. (Eds.), Ocean Margin Systems. Springer-Verlag Berlin Heidelberg, pp. 365-385.

Gerritsen, H.D., Minto, C., Lordan, C., 2013. How much of the seabed is impacted by mobile fishing gear? Absolute estimates from Vessel Monitoring System (VMS) point data. ICES Journal of Marine Science 70, 523-531. http://dx.doi.org/10.1093/icesjms/fst017.

Gomes-Pereira, J.N., Carmo, V., Catarino, D., Jakobsen, J., Alvarez, H., Aguilar, R., Hart, J., Giacomello, E., et al., 2017. Cold-water corals and large hydrozoans provide Essential Fish Habitat for Lappanella fasciata and Benthocometes robustus? Deep Sea Research Part II: Topical Studies in Oceanography. 145, 33-48.

Grehan, A.J., Unnithan, V., Olu, K., Opderbecke, J., 2005. Fishing impacts on Irish deep-water coral reefs: making the case for coral conservation. In: Thomas, J., Barnes, P. (Eds.),

Symposium on the Effects of Fishing Activities on Benthic Habitats: Linking Geology, Biology, Socioeconomics and Management. American Fisheries Society, Bethesda, Maryland, USA. , Tampa, USA, pp. 819-832.

Grehan, A.J., van den Hove, S., Armstrong, C.W., Long, R., van Rensburg, T., Gunn, V., Mikkelsen, E., De Mol, B., et al., 2009. HERMES: Promoting Ecosystem-Based Management and the Sustainable Use and Governance of Deep-Water Resources. Oceanography 22, 154-165. Harris, P.T., Whiteway, T., 2011. Global distribution of large submarine canyons: Geomorphic differences between active and passive continental margins. Marine Geology 285, 69-86. http://dx.doi.org/10.1016/j.margeo.2011.05.008.

Henry, L.A., Roberts, J.M., 2014. Recommendations for best practice in deep-sea habitat classification: Bullimore et al. as a case study. ICES Journal of Marine Science 71, 895-898. http://dx.doi.org/10.1093/icesjms/fst175. 
ICES. 2004. Ecoregions based on ICES Advice ACFM/ACE report. $\langle$ http://ices.dk/marine-data/maps/Documents/ICES_Ecoregions.pdf $\rangle$.

Kutti, T., Fossa, J.H., Bergstad, O.A., 2015. Influence of structurally complex benthic habitats on fish distribution. Marine Ecology Progress Series 520, 175-190. http://dx.doi.org/10.

3354/meps11047.

Kutti, T., Bergstad, O.A., Fosså, J.H., Helle, K., 2014. Cold-water coral mounds and sponge-beds as habitats for demersal fish on the Norwegian shelf. Deep-Sea Research Part II: Topical Studies in Oceanography 99, 122-133. http://dx.doi.org/10.1016/j.dsr2.2013.07.021. Lastras, G., Canals, M., Ballesteros, E., Gili, J.M., Sanchez-Vidal, A., 2016. Cold-water corals and anthropogenic impacts in la Fonera submarine canyon head, Northwestern Mediterranean Sea. PLoS ONE 11. http://dx.doi.org/10.1371/journal.pone.0155729.

Lavaleye, M., Duineveld, G., Bergman, M. \& van den Beld, I., 2017. Long-term baited lander experiments at a cold-water coral community on Galway Mound (Belgica Mound Province, NE Atlantic). Deep Sea Research Part II: Topical Studies in Oceanography, 145, 22-32. http://dx.doi.org/10.1016/j.dsr2.2015.12.014.

Linley, T.D., Lavaleye, M., Maiorano, P., Bergman, M., Capezzuto, F., Cousins, N.J., D’Onghia, G., Duineveld, G., et al., 2017. Effects of cold-water corals on fish diversity and density (European continental margin: Arctic, NE Atlantic and Mediterranean Sea): Data from three baited lander systems. Deep Sea Research Part II: Topical Studies in Oceanography, 145, 8-21. http://dx.doi.org/10.1016/j.dsr2.2015.12.003.

Maiorano, P., Sion, L., Capezzuto, F., Carlucci, R., Mastrototaro, F., Panza, M., Tursi, A., D’Onghia, G., 2013. Exploring deep-sea benthopelagic fauna using a baited lander in the Santa Maria di Leuca cold-water coral province. Rapp. Comm. int. Mer Médit 40, 719.

McLeod, K.L., Lubchenco, J., Palumbi, S.R., Rosenberg, A.A., 2005. Scientific Consensus Statement on Marine Ecosystem-Based Management. Signed by 221 academic scientists and policy ex- perts with relevant expertise and published by the Communication Partnership for Science and the Sea. Communication Partnership for Science and the Sea, USA 1-21.

Miller, R.J., Juska, C., Hocevar, J., 2015. Submarine canyons as coral and sponge habitat on the eastern Bering Sea slope. Global Ecology and Conservation 4, 85-94. http://dx.doi.org/ 10.1016/j.gecco.2015.05.009.

Mohn, C., Rengstorf, A., White, M., Duineveld, G., Mienis, F., Soetaert, K., Grehan, A., 2014. Linking benthic hydrodynamics and cold-water coral occurrences: A high-resolution model study at three cold-water coral provinces in the NE Atlantic. Progress in Oceanography 122, 92104. http://dx.doi.org/10.1016/j.pocean.2013.12.003.

Mortensen, P.B., Buhl-Mortensen, L., Gordon Jr, D.C., Fader, G.B.J., McKeown, D.L., Fenton, D.G., 2005. Effects of fisheries on deep-water gorgonian corals in the Northeast Channel, Nova Scotia (Canada). In: Barnes, P.W., Thomas, J.P. (Eds.), Benthic habitats and the effects of fishing. Am. Fish. Soc. Symp. 41. pp. 369-382.

Parra, H.E., Pham, C.K., Menezes, G.M., Rosa, A., Tempera, F. \& Morato, T., 2017. Predictive modeling of deep-sea fish distribution in the Azores. Deep Sea Research Part II: Topical Studies in Oceanography, 145,49-60. http://dx.doi.org/10.1016/j.dsr2.2016.01.004.

Pham, C.K., Gomes-Pereira, J.N., Isidro, E.J., Santos, R.S., Morato, T., 2013. Abundance of litter on Condor seamount (Azores, Portugal, Northeast Atlantic). Deep Sea Research Part II:

Topical Studies in Oceanography 98, 204-208. http://dx.doi.org/10.1016/j.dsr2.2013.01.011.

Pham, C.K., Vandeperre, F., Menezes, G., Porteiro, F., Isidro, E., Morato, T., 2015. The importance of deep-sea vulnerable marine ecosystems for demersal fish in the Azores. Deep-Sea

Research Part I: Oceanographic Research Papers 96, 80-88.

http://dx.doi.org/10.1016/j.dsr.2014.11.004.

Pham, C.K., Diogo, H., Menezes, G., Porteiro, F., Braga-Henriques, A., Vandeperre, F., Morato, T., 2014a. Deep-water longline fishing has reduced impact on Vulnerable Marine 
Ecosystems. Scientific Reports 4. http://dx.doi.org/10.1038/srep04837.

Pham, C.K., Ramirez-Llodra, E., Alt, C.H., Amaro, T., Bergmann, M., Canals, M., Company, J.B., Davies, J., et al., 2014b. Marine litter distribution and density in European seas, from the shelves to deep basins. PLoS ONE 9, e95839. http://dx.doi.org/10.1371/journal.pone.0095839. Ragnarsson, S.A., Burgos, J.M., Kutti, T., van den Beld, I., Egilsdóttir, H., Arnaud-Haond, S., Grehan, A., 2016. The Impact of Anthropogenic Activity on Cold-Water Corals. In: Rossi, S., Bramanti, L., Gori, A., Orejas, C. (Eds.), Marine Animal Forests: The Ecology of Benthic Biodiversity Hotspots. Springer International Publishing, pp. 1-35.

Rakka, M., Orejas, C., Sampaio, I., Monteiro, J., Parra, H. \& Carreiro-Silva, M., 2017. Reproductive biology of the black coral Antipathella wollastoni (Cnidaria: Antipatharia) in the Azores

(NE Atlantic). Deep Sea Research Part II: Topical Studies in Oceanography, 145,131-141. http://dx.doi.org/10.1016/j.dsr2.2016.05.011.

Rengstorf, A.M., Grehan, A., Yesson, C., Brown, C., 2012. Towards High-Resolution Habitat Suitability Modeling of Vulnerable Marine Ecosystems in the Deep-Sea: Resolving Terrain Attribute Dependencies. Marine Geodesy 35, 343-361.

http://dx.doi.org/10.1080/01490419.2012.699020.

Rengstorf, A.M., Yesson, C., Brown, C., Grehan, A.J., 2013. High-resolution habitat suitability modelling can improve conservation of vulnerable marine ecosystems in the deep sea. Journal of Biogeography 40, 1702-1714. http://dx.doi.org/10.1111/jbi.12123.

Rengstorf, A.M., Mohn, C., Brown, C., Wisz, M.S., Grehan, A.J., 2014. Predicting the distribution of deep-sea vulnerable marine ecosystems using high-resolution data: Considerations and novel approaches. Deep-Sea Research Part I: Oceanographic Research Papers 93, 72-82. http://dx.doi.org/10.1016/j.dsr.2014.07.007.

Roberts, J.M., Wheeler, A.J., Freiwald, A., 2006. Reefs of the deep: The biology and geology of cold-water coral ecosystems. Science 312, 543-547. http://dx.doi.org/10.1126/science.

1119861.

Rodríguez, Y., Pham, C.K., 2017. Marine litter on the seafloor of the Faial-Pico Passage, Azores Archipelago. Marine Pollution Bulletin 116, 448-453. http://dx.doi.org/10.1016/j.

marpolbul.2017.01.018.

Rogers, A.D., Brierley, A., Croot, P., Cunha, M.R., Danovaro, R., Devey, C., Hoel, A.H., Ruhl, H.A. (Eds.), 2015. Delving Deeper: Critical challenges for 21st century deep-sea research.

Ostend, Belgium, pp. 1-224.

Ross, S.W., Rhode, M., Quattrini, A.M., 2015. Demersal fish distribution and habitat use within and near Baltimore and Norfolk Canyons, U.S. middle Atlantic slope. Deep-Sea Research

Part I: Oceanographic Research Papers 103, 137-154. http://dx.doi.org/10.1016/j.dsr.2015.06.004. Savini, A., Vertino, A., Marchese, F., Beuck, L., Freiwald, A., 2014. Mapping cold-water coral habitats at different scales within the Northern Ionian Sea (central Mediterranean): An assessment of coral coverage and associated vulnerability. PLoS ONE 9.

http://dx.doi.org/10.1371/journal.pone.0087108.

Sion, L., Capezzuto, F., Carlucci, R., Carluccio, A., Indennidate, A., Maiorano, P., D'Onghia, G., 2013. Behaviour of deep-sea sharks observed in the Santa Maria di Leuca cold-water coral province. Rapp. Comm. int. Mer Médit 40, 494.

Soetaert, K., Mohn, C., Rengstorf, A., Grehan, A., van Oevelen, D., 2016. Ecosystem engineering creates a direct nutritional link between 600-m deep cold-water coral mounds and surface productivity. Scientific Reports 6 http://doi.org/ARTN.35057.10.1038/srep35057.

Taviani, M., Angeletti, L., Canese, S., Cannas, R., Cardone, F., Cau, A., Cau, A.B., Follesa, M.C., et al., 2017. The "Sardinian cold-water coral province" in the context of the Mediterranean coral ecosystems. Deep Sea Research Part II: Topical Studies in Oceanography, 145,61-78. http://dx.doi.org/10.1016/j.dsr2.2015.12.008. 
Taylor, M.L., Roterman, C.N., 2017. Invertebrate population genetics across Earth's largest habitat: The deep-sea floor. Mol Ecol. http://dx.doi.org/10.1111/mec.14237.

Taylor, M.L., Gwinnett, C., Robinson, L.F., Woodall, L.C., 2016. Plastic microfibre ingestion by deep-sea organisms. Sci Rep 6, 33997. http://dx.doi.org/10.1038/srep33997.

Thurber, A.R., Sweetman, A.K., Narayanaswamy, B.E., Jones, D.O.B., Ingels, J., Hansman, R.L., 2014. Ecosystem function and services provided by the deep sea. Biogeosciences 11, 3941-3963. http://dx.doi.org/10.5194/bg-11-3941-2014.

van den Beld, I.M.J., Guillaumont, B., Menot, L., Bayle, C., Arnaud-Haond, S. \& Bourillet, J.-F., 2017. Marine litter in submarine canyons of the Bay of Biscay. Deep Sea Research Part II:

Topical Studies in Oceanography, 145,142-152. http://dx.doi.org/10.1016/j.dsr2.2016.04.013. van den Beld, I.M.J., Bourillet, J.F., Arnaud-Haond, S., de Chambure, L., Davies, J.S., Guillaumont, B., Olu, K., Menot, L., 2017. Cold-water coral habitats in submarine canyons of the Bay of Biscay. Frontiers in Marine Science 4. http://dx.doi.org/10.3389/fmars.2017.00118.

Van Oevelen, D., Duineveld, G., Lavaleye, M., Mienis, F., Soetaert, K., Heip, C.H.R., 2009. The cold-water coral community as a hot spot for carbon cycling on continental margins: A foodweb analysis from rockall bank (northeast atlantic). Limnology and Oceanography 54, 1829-1844.

Weaver, P.P.E., Boetius, A., Danovaro, R., Freiwald, A., Gunn, V., Heussner, S., Morato, T., Schewe, I., et al., 2009. The future of integrated deep-sea research in Europe: The HERMIONE project. Oceanography 22, 178-191.

Wilson, J.B., 1979. 'Patch' development of the deep-water coral Lophelia pertusa (L.) on Rockall Bank. Journal of the Marine Biological Association of the United Kingdom 59, 165-177.

Woodall, L.C., Sanchez-Vidal, A., Canals, M., Paterson, G.L., Coppock, R., Sleight, V., Calafat, A., Rogers, A.D., et al., 2014. The deep sea is a major sink for microplastic debris. R Soc Open Sci 1, 140317. http://dx.doi.org/10.1098/rsos.140317.

Yesson, C., Clark, M.R., Taylor, M.L., Rogers, A.D., 2011. The global distribution of seamounts based on 30 arc seconds bathymetry data. Deep Sea Research Part I: Oceanographic Research Papers 58, 442-453. http://dx.doi.org/10.1016/j.dsr.2011.02.004.

Yesson, C., Bedford, F., Rogers, A.D. \& Taylor, M.L., 2017. The global distribution of deep-water Antipatharia habitat. Deep Sea Research Part II: Topical Studies in Oceanography, 145,79-86. http://dx.doi.org/10.1016/j.dsr2.2015.12.004.

Yesson, C., Taylor, M.L., Tittensor, D.P., Davies, A.J., Guinotte, J., Baco, A., Black, J., HallSpencer, J.M., et al., 2012. Global habitat suitability of cold-water octocorals. Journal of Biogeography 39, 1278-1292. http://dx.doi.org/10.1111/j.1365-2699.2011.02681.x. 